\title{
O perfil dos investimentos brasileiros na infraestrutura de armazenamento de etanol: desafios e tendências da Cadeia Produtiva
}

\author{
Ana Carolina Spatti (IC), Maria Ester Soares Dal Poz (PQ).
}

\section{Resumo}

Diante da constatação do crescimento da demanda por etanol e da consolidação das organizações em rede, a pesquisa buscou investigar o perfil brasileiro dos investimentos em armazenagem do etanol de cana-de-açúcar, de maneira a oferecer informações pertinentes aos interessados e envolvidos no setor quanto às principais questões de armazenagem, contribuindo, assim, tanto para a indústria quanto para a Academia.

Palavras Chave: Bioetanol, logística, gargalos tecnológicos.

\section{Introdução}

Frente à importância que o etanol tem representado em âmbito mundial, o presente trabalho pretende: realizar um estudo acerca das políticas energéticas mundiais; investigar o perfil brasileiro dos investimentos em armazenagem do etanol de cana-de-açúcar; propor um redesenho da cadeia produtiva que inclua de modo mais explícito o processo de armazenagem, considerando essa atividade como parte essencial da cadeia produtiva, e não como acessória; verificar quais os gargalos tecnológicos $\mathrm{e}$ as tendências de investimentos e esforços organizacionais nas atividades de armazenamento para os próximos anos.

\section{Resultados e Discussão}

Em virtude do projeto ter sido cancelado antes do prazo previsto (com 5 meses), não foram cumpridos todos os objetivos propostos. Os principais resultados obtidos até o momento tomam corpo na figura a seguir.

Figura 1. Cadeia Produtiva agroindustrial do Etanol

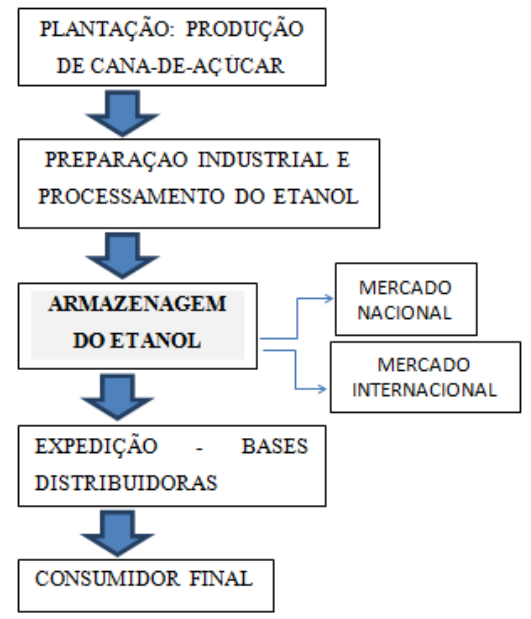

Fonte: Elaboração própria com base em Goes (2008).
Embora a proposta de Goes (2008) de mapeamento da cadeia seja um pouco mais detalhada que a de Roessing (2002), ambas se assemelham bastante e não incluem de modo explícito uma etapa fundamental, objeto do presente estudo: a etapa/atividade de armazenagem do etanol.

\section{Conclusões}

Percebe-se que houve o acréscimo da atividade de armazenagem do etanol entre as etapas de processamento do produto e expedição, pois se entende que, muitas vezes, entre 0 processamento de etanol e a expedição para as bases distribuidoras, há um intervalo de tempo no qual o produto fica estocado até que a expedição se efetive.

\section{Agradecimentos}

Agradeço à orientadora Maria Ester Soares Dal Poz pela oportunidade de realizar essa pesquisa.

Agradeço também ao Conselho Nacional de Desenvolvimento Científico e Tecnológico.

GOES, Carla G. F. S.. Análise da estrutura produtiva da cadeia do etanol no Brasil. Disponível em:

<http://portal.fei.edu.br/Download\%20de\%20Pesquisas/AnaliseDaEs truturaProdutiva.pdf 2008>. Acesso em 20 de nov. 2014.

ROESSING, Antonio C. Cadeias produtivas: roteiro para estudo de sistemas agroalimentares . Londrina: Embrapa Soja, 2002. Disponível em

$<$ http://ainfo.cnptia.embrapa.br/digital/bitstream/item/80229/1/Cadei as-produtivas-roteiro-para-estudo-de-sistemas-agroalimentares.pdf $>$. Acesso em 11 de nov. 2014. 